\title{
The 8Ps Marketing Mix and the Buyer Decision-Making Process
}

\author{
Lucinda L. Parmer \\ Southeastern Oklahoma State University
}

\author{
John E. Dillard, Jr. \\ University of Houston-Downtown
}

Ying-Chou Lin

Southeastern Oklahoma State University

The 8 Ps marketing mix consists of (1) service product; (2) price; (3) place; (4) promotion; (5) people; (6) process; (7) physical evidence; and (8) productivity (Booms \& Bitner, 1980; 1981). The buyer decisionmaking process consists of five stages to include (1) need recognition; (2) information search; (3) evaluation of alternatives; (4) purchase decision; and (5) post-purchase evaluation (Dewey, 1910; Engel, et al., 1978; 1986). This paper utilized a sample size of 426 participates to examine these two constructs of the 8 Ps marketing mix and the decision-making process, along with the socio-demographics of age; gender; ethnicity; socio-economic level; and education level. Tukey's Honest Significant Difference PostHoc Analysis found multiple significant relationships $(p<.05)$.

Keywords: 8 Ps marketing mix, buyer decision-making process, decision-making, services marketing, service-oriented products

\section{INTRODUCTION}

The tracking of service-oriented products is a complicated process. Service-oriented products are intangible; perishable; heterogenic; inseparable yet provide benefits to the customer. A haircut and a car oil change are examples of service-oriented products. The marketing and promoting of service-oriented products can be challenging and cause product confusion due to the intangibility factor. As a result, serviceoriented products are difficult for companies regarding the tracking of consumer spending habits; product positioning; differentiation among competitors as well as challenging to sell (Bhattacharya, 2013; Wirtz, 2020; Yang et al., 2015).

However, tangible products can be felt, for example, when purchasing a bottle of shampoo or buying a car. Companies such as Kroger and CVS, use consumer tracking systems with barcode key tags (or cards) to track tangible products. When the customer scans the bar code key tag at the checkout register, the details of the transaction are recorded, and discounts may be provided on the purchased items. This barcode data can be collected in a variety of ways. For example, it can be collected at the point-of-sale inside the brickand-mortar store or on the digital storefront, such as, at www.kroger.com or www.cvs.com. The barcode 
scanner tracks consumer spending habits, socio-demographic profiles, as well as it is used by companies to adjust pricing and inventory (Basker, 2015; Berry, 2013; Kruger, 2005).

Understanding service-oriented product purchase behavior and intent are important. Consumers today can instantaneously leave negative comments on social media outlets such as Facebook, Instagram, yelp.com, and Angie's List. Online customer reviews are peer-generated and customers will use social media or third-party platforms to show support for purchase or not (Haddara et al., 2020). Negative reviews regarding services received at a hair salon; restaurant; car dealership; or a dry cleaner, for example, can damage reputations. The reputations of both the person who performed the service and the business where the service was performed are at risk This paper aims to understand service-oriented product purchase behavior and intent in relation to the 8 Ps marketing mix and the buyer decision-making process. Sociodemographic data were also examined.

\section{Ps MARKETING MIX}

The prior literature was limited with having studies that included the 8 Ps marketing mix and the buyer decision-making process constructs researched together. This research study adds to the literature in an area where there was a noticeable gap. However, it was found in the prior literature that the 8 Ps marketing mix was designed more so for private companies looking to establish competitive advantages with service products (Mathur, 2018). Moreover, the person performing the service; the physical evidence pertaining to the service; and service productivity were significantly related to enhancing a brand's image and brand equity (Mukherjee \& Shivani, 2016).

Additionally, it was found that the elements of the 8 Ps marketing mix to include service product; price; place; person; and productivity had significant relationships with the rate of sales a company obtained (Heidari, 2017). Furthermore, all elements of the 8 Ps marketing mix impacted a person's decision about purchasing accounting services, as well as, having a long-term relationship with the firm providing these types of services (Bushong \& Koku, 2012). It was also found that when the 8 Ps marketing mix was implemented successfully, it led to higher customer satisfaction ratings; more company profits; and a larger market share (Lovelock \& Wright, 2002; Vaccaro \& Cohn, 2004). It was further determined that any wrong combination of the 8 Ps marketing mix could produce bad results for a company (Nyarku \& Agyapong, 2011). It was also found that the 8 Ps marketing mix framework was most beneficial for service-oriented products within the private business sector when having a competitive advantage was important (Mathur, 2018).

Additionally, the extended services marketing mix aimed to establish meeting the service needs of the consumer; provided benefits to the consumer from purchasing the service; as well as, solved a problem for the consumer through the service-oriented product purchase. Additionally, the productivity and quality element of the 8 Ps marketing mix became strategic initiatives that companies looked to obtain through organizational service-product offerings. However, this was challenging to achieve due to the high expectations that consumers had on the services that were purchased (Coculescu, et al., 2016). It was determined that the success of banking and credit services was based on the credibility of the service with profits being generated from having satisfied customers. Therefore, it is important for financial institutions to meet customer expectations when selling banking service-oriented products (Kesavan \& Vanniarajan, 2016).

Moreover, it was shown that within the promotion element of the services marketing mix, advertising was a tool that was used frequently by companies. The competition was tough within the service industry and companies would try to out-spend one another. For example, it is not uncommon for Bank of America and JP Morgan Chase to spend \$1 billion in annual advertising efforts (Stafford, 2011).

\section{BUYER DECISION-MAKING PROCESS}

The authors found in the prior literature that the way consumers organized information mentally about a brand or product influenced the purchase process (Lala, 2016). With new products entering the 
marketplace, consumers based purchase decisions on product features and benefits. However, the price of the product was the least influential on the decision to purchase. It was further determined that promotions; price; and product elements, such as packaging and features determined consumer repurchase behavior (Thaichon et al., 2018). Moreover, when a customer decided to purchase a product, an automated decision process approach could transpire prior to this purchase. Additionally, consumers would purchase a product based on the psychological need the product was fulfilling, including status, customer's value-based system, or the customer's lifestyle (Stoica, et al., 2018).

Furthermore, the decision-making process took on a rational approach when the consumer systematically went through the steps with the mindset of determining how the service would fill a void. Some consumers would quickly go through the steps in the decision-making process. However, skipping the evaluation of alternatives step was common when the consumer was brand loyal. Females were more inclined to consult with friends and family when researching product alternatives. Females were more likely to recommend a particular service when highly satisfied with the service. Females were also more likely to disclose dissatisfaction about a service to friends and family (Koban-Roess, 2013).

It was further determined that one of the goals a company had was to understand buyer behavior from the stimulus point when a customer realized there was a need for a product. Likewise, an external activity such as the product promotions the company was offering could be influential within the buyer decisionmaking process (Svatošová, 2013). Moreover, it was identified that one of the most common events a consumer did was make purchase decisions on products or services (Branchik \& Shaw, 2015).

Additionally, it was shown that the decision-making process happened multiple times throughout the day. For example, as with deciding which restaurant to go to for breakfast, or what to order for breakfast. Therefore, the need to reduce cognitive dissonance and regret regarding decision-making was important for companies. The decision-making process did require choosing between alternative courses of action, and this selection during the post-purchase evaluation phase was where regret and cognitive dissonance could happen (Joseph-Williams, et al., 2011). Lastly, another study found that external factors were influential regarding the buyer decision-making process. However, advertising was the most reliable tool for communicating the service-product message (Shrivastava \& Bisen, 2014).

\section{THEORETICAL FRAMEWORK}

The theoretical framework used in this study was the 8 Ps marketing mix (Booms \& Bitner, 1980; 1981) and the buyer decision-making process (Dewey, 1910; Engel, et al., 1978; 1986). The 8 Ps marketing mix includes the service product; price; place; promotion; people; process; physical evidence; and productivity. The buyer decision-making process includes need recognition; information search; evaluation of alternatives; purchase decision; and post-purchase behavior.

\section{RESEARCH QUESTIONS (RQ)}

The following research questions were established to guide this study.

RQ1: What role does the 8 Ps marketing mix of service product; price; place; promotion; people; process; physical evidence; and productivity have on the buyer decision-making process of need recognition; information search; evaluation of alternatives; purchase decision; and post-purchase behavior?

RQ2: What role does the 8 Ps marketing mix of service product; price; place; promotion; people; process; physical evidence; and productivity have on the socio-demographics of gender; age; ethnicity; socioeconomic level; and education level?

RQ3: What role does the buyer decision-making process of need recognition; information search; evaluation of alternatives; purchase decision; and post-purchase behavior have on the socio-demographics of gender; age; ethnicity; socioeconomic level; and education level? 


\section{DEFINITION OF KEY TERMS}

The 8 Ps marketing mix is made up of eight elements to include the service product; price; place; promotion; people; process; physical evidence; and productivity. Service product is defined as the core benefit associated with the service and any extra product features related to the use; distribution; and procurement of the service product. Price is defined as the financial costs associated with the service product and any additional nonfinancial costs such as waiting times and physical or mental exertions. Place [emphasis added] is defined as where the service is attained either from brick-and-mortar stores, the Internet, or home delivery.

Promotion is defined as the ways that a service product is communicated in order to persuade consumers to buy. These communications can come through multi-media to include the Internet; audio and video broadcasts; print media; salespeople; and word-of-mouth, for example. People are defined as the person performing the service for the customer. Process is defined as the steps involved to complete the service for the customer.

Physical evidence is defined as the company's tangible and noticeable characteristics associated with the image and perceived value of the service. Productivity is defined as the level of proficiency and effectiveness a company has at producing service quality and value for the customer (Lovelock \& Wright, 2002; Vaccaro \& Cohn, 2004).

The buyer decision-making process contains five elements to include need recognition; information search; evaluation of alternatives; purchase decision; and post-purchase behavior. Need recognition is defined as when someone recognizes there is a need, and a service-oriented product can fill this need. Information search is defined as looking for information about a service product that will best suit the need. Evaluation of alternatives is defined as the value gained by purchasing a particular service-oriented product over another. Purchase decision is defined as the selecting of a service product and the point where it is actually purchased. Lastly, post-purchase behavior is defined as the level of satisfaction obtained from the service or the likelihood of complaining about the service (Moore, et al., 2020; Tevšić \& Nanić, 2020).

\section{METHOD}

\section{Overview}

This was an empirical study examining the relationships between the 8 Ps marketing mix of service product; price; place; promotion; people; process; physical evidence; and productivity and the buyer decision-making process of need recognition; information search; evaluation of alternatives; purchase decision; and post-purchase behavior. The Services Decision-Making Survey (SDMS) (Parmer \& Lin) was used to measure the participants' importance preferences in relation to the 8 Ps marketing mix and the buyer decision-making process. Socio-demographic variables were likewise accessed.

\section{Research Instrument}

The SDMS contained 20 items measuring the participants' importance preferences regarding the 8 Ps marketing mix and the buyer decision-making process when purchasing service-oriented products. Likewise, socio-demographic questions were asked of the participants. The SDMS was administered in one form created with the SurveyMonkey web-based platform. The survey had four sections, a consent section; the 8 Ps marketing mix questions; the buyer decision-making process questions; and the socio-demographic questions.

\section{Participants}

The sample consisted of 426 participants $(n=426)$ gathered digitally in the United States.

\section{Hypotheses $(H)$}

The authors tested the following three hypotheses. 
$\boldsymbol{H}_{1}$ : There is a significant relationship between the 8 Ps marketing mix of service product; price; place; promotion; people; process; physical evidence; and productivity; and the buyer decision-making process of need recognition; information search; evaluation of alternatives; purchase decision; and post-purchase evaluation.

$\boldsymbol{H}_{2}$ : There is a significant relationship between the 8 Ps marketing mix of service product; price; place; promotion; people; process; physical evidence; and productivity and the socio-demographics of age; gender; ethnicity; socioeconomic level; and education level.

$\boldsymbol{H}_{3}:$ There is a significant relationship between the buyer decision-making process of need recognition; information search; evaluation of alternatives; purchase decision; and post-purchase evaluation; and the socio-demographics of age; gender; ethnicity; socioeconomic level; and education level.

\section{STATISTICAL ANALYSIS}

This study sought to establish the relationship between the 8 Ps marketing mix of service product; price; place; promotion; people; process; physical evidence; and productivity, and the buyer decision-making process of need recognition; information search; evaluation of alternatives; purchase decision; and postpurchase evaluation. Socio-demographic variables were likewise accessed. This study used the IBM SPSS v27 statistical analysis platform. Additionally, G*Power was used to validate the sampling adequacy (Ahmad, 2018). The minimum suggested sample size was 189 participants, and the non-centrality parameter was $\lambda=28.35 ; F(13,175)=1.776$, with an achieved power of 0.951 .

The sample size of this study was 426 participants which were more than enough, meaning that the sampling adequacy assumption was not violated and that the results were representative (Newsom, 2018). To test the reliability of the constructs, Cronbach's alpha was computed, and the 8 Ps marketing mix generated, $\alpha_{8 \mathrm{Ps}}=0.845$, and the buyer decision-making process generated $\alpha_{\mathrm{BDMP}}=0.781$. Both alpha coefficients were greater than the prescribed minimum of 0.70 meaning that both constructs were reliable (Dugard et al., 2010; Dimitrov, 2014; Belhekar, 2016). Statistically significant p-values $(p<.05)$ are indicated in bold on the forthcoming tables.

\section{RESULTS}

\section{Socio-Demographic Analysis}

This study considered the socio-demographic variables of age; gender; ethnicity; socioeconomic level; and education level. Cumulatively, those aged between 18 - 39 years old represented $76.0 \%$ of the sample. The least aged group was 60 years old or higher $(0.7 \%)$. Females $(57.2 \%)$ were represented more so over males (42.8\%). The White ethnic group was the majority of the respondents $(47.8 \%)$, followed by the Black ethnic group (17.9\%). The third highest ethnic group was Hispanic (16.9\%). The modal socioeconomic level group earned more than $\$ 86,000(26.8 \%)$, followed by those who earned between $\$ 46,000-\$ 65,000$ $(21.4 \%)$. The least socioeconomic group earned $\$ 25,000$ or less $(13.6 \%)$. The majority of this sample had attained a bachelor's degree (59.3\%).

\section{Hierarchical Multiple Linear Regression}

The first goal of this study was to determine the relationship between the 8 Ps marketing mix independent variables of service product; price; place; promotion; people; process; physical evidence; and productivity, the buyer decision-making process dependent variables of need recognition; information search; evaluation of alternatives; purchase decision; and post-purchase evaluation, and the sociodemographic variables of age; gender; ethnicity; socioeconomic level; and education level.

Since there was a need to control for the effect of the socio-demographic variables, hierarchical multiple linear regression was initiated. The explanatory variables that were included in Model 1 were age; gender; 
ethnicity; socioeconomic level; and education level. Model 2 comprised both the socio-demographic variables and the 8 Ps marketing mix variables.

As indicated in Table 1, the socio-demographic variables alone in Model 1 were statistically significant for two of the five buyer decision-making process dependent variables, that is, information search and purchase decision. As shown in Model 2, the inclusion of the 8 Ps marketing mix variables while controlling the socio-demographic variables increased the predictive capacity of all five buyer decision-making process variables. Autocorrelation was further tested using the Durbin-Watson test and all the coefficients computed approximated 2.0, meaning that the auto-correlation assumption was not violated (Field, 2016).

TABLE 1

HIERARCHICAL REGRESSION MODEL SUMMARY

\begin{tabular}{|c|c|c|c|c|c|c|c|c|c|c|c|}
\hline \multirow[b]{2}{*}{ DV } & \multirow[b]{2}{*}{ Model } & \multirow[b]{2}{*}{$\mathrm{R}$} & \multirow[b]{2}{*}{$\mathrm{R}^{2}$} & \multirow[b]{2}{*}{$\begin{array}{l}\text { Adj. } \\
\mathrm{R}^{2}\end{array}$} & \multirow[b]{2}{*}{ SE } & \multicolumn{5}{|c|}{ Change Statistics } & \multirow[b]{2}{*}{$\begin{array}{l}\text { Durbin- } \\
\text { Watson }\end{array}$} \\
\hline & & & & & & $\Delta \mathrm{R}^{2}$ & $\Delta \mathrm{F}$ & df1 & df2 & $\mathrm{p}(\Delta \mathrm{F})$ & \\
\hline \multirow{2}{*}{$\begin{array}{l}\text { Need } \\
\text { recognition }\end{array}$} & 1 & $.136^{\mathrm{a}}$ & .019 & .007 & .941 & .019 & 1.585 & 5 & 419 & .163 & \\
\hline & 2 & $.272^{\mathrm{b}}$ & .074 & .045 & .923 & .055 & 3.076 & 8 & 411 & .002 & 2.031 \\
\hline \multirow{2}{*}{$\begin{array}{l}\text { Information } \\
\text { search }\end{array}$} & 1 & $.193^{\mathrm{a}}$ & .037 & .026 & .920 & .037 & 3.244 & 5 & 419 & .007 & \\
\hline & 2 & $.396^{\mathrm{b}}$ & .157 & .130 & .869 & .120 & 7.286 & 8 & 411 & .000 & 1.979 \\
\hline \multirow{2}{*}{$\begin{array}{l}\text { Evaluation } \\
\text { of } \\
\text { alternatives }\end{array}$} & 1 & $.057^{\mathrm{a}}$ & .003 & -.009 & .941 & .003 & .268 & 5 & 417 & .931 & \\
\hline & 2 & $.363^{\mathrm{b}}$ & .132 & .105 & .887 & .129 & 7.593 & 8 & 409 & .000 & 1.951 \\
\hline \multirow{2}{*}{$\begin{array}{l}\text { Purchase } \\
\text { decision }\end{array}$} & 1 & $.196^{\mathrm{a}}$ & .038 & .027 & 1.175 & .038 & 3.353 & 5 & 419 & .006 & \\
\hline & 2 & $.408^{\mathrm{b}}$ & .166 & .140 & 1.105 & .128 & 7.875 & 8 & 411 & .000 & 1.952 \\
\hline \multirow{2}{*}{$\begin{array}{l}\text { Post- } \\
\text { purchase } \\
\text { evaluation }\end{array}$} & 1 & $.046^{\mathrm{a}}$ & .002 & -.010 & .927 & .002 & .181 & 5 & 419 & .970 & \\
\hline & 2 & $.297^{\mathrm{b}}$ & .088 & .059 & .895 & .086 & 4.835 & 8 & 411 & .000 & 1.996 \\
\hline
\end{tabular}

a. Predictors: (Constant) age; gender; ethnicity; socioeconomic level; education level

b. Predictors: (Constant) age; gender; ethnicity; socioeconomic level; education level; service product, price; place; promotion; people; process; physical evidence; productivity

Multicollinearity was tested using the Variance Inflation Factor (VIF), with a prescribed maximum tolerable VIF of 3.0 (Dimitrov, 2014). None of the VIFs were greater than 3.0, meaning that the multicollinearity assumption was not violated. Hierarchical multiple linear regression was then further initiated, and Table 2 represents the hierarchical regression coefficients. The results show that socioeconomic level was significant with need recognition, and ethnicity and education level were significant with information search and purchase decision. However, none of the socio-demographic variables influenced the evaluation of alternatives or the post-purchase evaluation of the buyer decisionmaking process.

The results further establish that when controlling for the socio-demographic variables, socioeconomic level; promotion; and process were statistically significant with need recognition. Moreover, age; promotion; people; process; and productivity were statistically significant with information search. Also, promotion; physical evidence; and productivity were statistically significant with the evaluation of alternatives. Additionally, age; people; process; physical evidence; and productivity were statistically significant with the purchase decision. Lastly, productivity proved to be statistically significant with postpurchase evaluation. 
TABLE 2

HIERARCHICAL REGRESSION COEFFICIENTS

\begin{tabular}{|c|c|c|c|c|c|c|c|c|c|c|c|}
\hline & & \multicolumn{2}{|c|}{$\begin{array}{l}\text { Need } \\
\text { Recognition }\end{array}$} & \multicolumn{2}{|c|}{$\begin{array}{l}\text { Information } \\
\text { search }\end{array}$} & \multicolumn{2}{|c|}{$\begin{array}{l}\text { Evaluation of } \\
\text { alternatives }\end{array}$} & \multicolumn{2}{|c|}{$\begin{array}{l}\text { Purchase } \\
\text { decision }\end{array}$} & \multicolumn{2}{|c|}{$\begin{array}{l}\text { Post-purchase } \\
\text { evaluation }\end{array}$} \\
\hline & & $\beta$ & $\mathrm{p}$ & $\beta$ & $\mathrm{p}$ & $\beta$ & $\mathrm{p}$ & $\beta$ & $\mathrm{p}$ & $\beta$ & $\mathrm{p}$ \\
\hline \multirow[t]{6}{*}{1} & (Constant) & & .000 & & .000 & & .000 & & .000 & & .000 \\
\hline & Age & -.019 & .728 & -.077 & .152 & -.011 & .838 & -.096 & .071 & -.033 & .541 \\
\hline & Gender & -.071 & .149 & -.074 & .125 & -.010 & .847 & .051 & .289 & .000 & .994 \\
\hline & Ethnicity & -.038 & .435 & .098 & .044 & .047 & .341 & .114 & .019 & .018 & .710 \\
\hline & $\begin{array}{l}\text { Socioeconomic } \\
\text { level }\end{array}$ & .121 & .034 & .094 & .098 & .016 & .778 & -.050 & .378 & -.007 & .909 \\
\hline & Education level & .010 & .853 & .103 & .048 & .022 & .673 & .121 & .021 & -.012 & .815 \\
\hline \multirow[t]{14}{*}{2} & (Constant) & & .000 & & .014 & & .073 & & .000 & & .000 \\
\hline & Age & -.046 & .391 & -.128 & .013 & -.052 & .317 & -.112 & .028 & -.076 & .158 \\
\hline & Gender & -.056 & .250 & -.028 & .551 & .027 & .572 & .086 & .064 & .031 & .521 \\
\hline & Ethnicity & -.076 & .119 & .064 & .169 & .018 & .697 & .081 & .081 & -.008 & .870 \\
\hline & $\begin{array}{l}\text { Socioeconomic } \\
\text { level }\end{array}$ & .157 & .008 & .107 & .058 & .031 & .588 & -.014 & .803 & .008 & .888 \\
\hline & Education level & -.028 & 601 & .068 & 183 & -.011 & .825 & .077 & .128 & -.041 & .440 \\
\hline & Product & -.237 & .097 & -.052 & .699 & -.049 & .723 & -.058 & .667 & -.011 & .935 \\
\hline & Price & .220 & .126 & .155 & .258 & .127 & .363 & .032 & .816 & .039 & .783 \\
\hline & Place & -.024 & .647 & .054 & .268 & -.021 & .667 & -.050 & .303 & -.022 & .673 \\
\hline & Promotion & .111 & .030 & .110 & .024 & .128 & .010 & .057 & .237 & .068 & .177 \\
\hline & People & .001 & .978 & .133 & .006 & .050 & .318 & .124 & .011 & .082 & .106 \\
\hline & Process & .131 & .015 & .106 & .038 & .062 & .236 & .147 & .004 & .087 & .102 \\
\hline & Physical evidence & .052 & .319 & .050 & .308 & .117 & .020 & .156 & .002 & .085 & .098 \\
\hline & Productivity & .079 & .131 & .136 & .006 & .237 & .000 & .242 & .000 & .183 & .000 \\
\hline
\end{tabular}

\section{Multivariate Analysis of Variance (MANOVA)}

To determine the impact of the socio-demographic variables on the buyer decision-making process and the 8Ps marketing mix, factorial MANOVA was initiated. To validate the use of this test, two assumptions were tested (Field, 2016). These assumptions included the Box's Test for Equivalence of Covariance Matrices and Levene's Test for Equality of Variances. The assumption of the equality of covariance matrices were not violated for both constructs $(F(180,4318)=1.027 ; p=0.389 ; F(36,946)=0.692 ; p=$ 0.915 , respectively). Likewise, the assumption of the equality of error variances was not violated for all the five buyer decision-making process variables and all the 8Ps marketing mix variables. Furthermore, the effect of the socio-demographic variables on the two constructs was tested using the factorial MANOVA. The MANOVA analysis is provided in Table 3 below for the buyer decision-making process variables. This analysis indicated that five of the 8 Ps marketing mix variables were significant predictors of the buyer decision-making process to include promotion; people; process; physical evidence; and productivity. Among the socio-demographic variables, two were significant predictors of the buyer decision-making process to include age and socioeconomic level. 
TABLE 3

MANOVA ANALYSIS P-VALUES - BUYER DECISION-MAKING PROCESS

\begin{tabular}{llllll}
\hline & $\begin{array}{l}\text { Need } \\
\text { Recognition }\end{array}$ & $\begin{array}{l}\text { Information } \\
\text { search }\end{array}$ & $\begin{array}{l}\text { Evaluation of } \\
\text { alternatives }\end{array}$ & $\begin{array}{l}\text { Purchase } \\
\text { decision }\end{array}$ & $\begin{array}{l}\text { Post-purchase } \\
\text { evaluation }\end{array}$ \\
\hline Product & .691 & .537 & .890 & .967 & .313 \\
Price & .966 & .358 & .679 & .914 & .525 \\
Place & .680 & .060 & .805 & .230 & .989 \\
Promotion & $\mathbf{. 0 1 9}$ & $\mathbf{. 0 1 8}$ & $\mathbf{. 0 4 7}$ & .213 & .466 \\
People & .791 & $\mathbf{. 0 0 0}$ & .435 & $\mathbf{. 0 0 9}$ & .224 \\
Process & $\mathbf{. 0 1 3}$ & $\mathbf{. 0 2 7}$ & .691 & $\mathbf{. 0 1 4}$ & .710 \\
Physical evidence & .093 & .561 & $\mathbf{. 0 3 1}$ & $\mathbf{. 0 0 5}$ & .129 \\
Productivity & .838 & $\mathbf{. 0 0 5}$ & $\mathbf{. 0 0 0}$ & $\mathbf{. 0 0 1}$ & $\mathbf{. 0 0 6}$ \\
\hline Age & .269 & $\mathbf{. 0 1 8}$ & .507 & $\mathbf{. 0 2 6}$ & .602 \\
Gender & .509 & .364 & .665 & .320 & .496 \\
Ethnicity & .599 & .105 & .480 & .576 & .448 \\
Socioeconomic level & $\mathbf{. 0 1 5}$ & .434 & .431 & .539 & .967 \\
Education level & .766 & .404 & .105 & .660 & .412 \\
\hline
\end{tabular}

The MANOVA analysis for the 8 Ps marketing mix variables is provided in Table 4. The analysis indicated that two of the socio-demographic variables were significant predictors of the 8 Ps marketing mix to include socioeconomic level and education level.

TABLE 4

MANOVA ANALYSIS P-VALUES - 8 Ps MARKETING MIX

\begin{tabular}{lllllllll}
\hline & & & & & & \multicolumn{3}{c}{ Physical } \\
& Product & Price & Place & Promotion & People & Process & evidence & Productivity \\
\hline Age & .465 & .278 & .112 & .906 & .914 & .194 & .087 & .761 \\
Gender & .961 & .864 & .358 & .957 & .268 & .799 & .911 & .529 \\
Ethnicity & .081 & .184 & .939 & .307 & .265 & .292 & .113 & .907 \\
$\begin{array}{l}\text { Socioeconomic } \\
\text { level }\end{array}$ & & & & & & & & \\
Education level & .066 & .070 & .512 & $\mathbf{. 0 1 7}$ & .778 & $\mathbf{. 0 0 8}$ & .954 & .420 \\
\hline
\end{tabular}

\section{Tukey's Honest Significant Difference Post-Hoc Analysis}

Having established that age had an influence on both information search and purchase decision, and socioeconomic level had an influence on need recognition, the Tukey's honest significant difference (HSD) post-hoc test was initiated to establish the significant sub-group relationships (Jaggia \& Kelly, 2013; Holmes, et al., 2017). The post-hoc analysis for age and information search is provided in Table 5. To minimize the number of tables provided in this paper, the remaining Tukey's HSD post-hoc analysis has been summarized.

The results show that regarding age and information search, younger participants did more information searching on service-oriented products. The respondents aged 60 years or older rated the importance of information search the least. To establish whether the differences were significant, the Tukey's HSD posthoc test was carried out and information search was statistically significant $(p<.05)$ between all three younger age groups of $18-29 ; 30-39$; and $40-49$ years old, and the oldest age group of 60 years of age or older. 
TABLE 5

TUKEY HSD - POST-HOC TEST FOR AGE AND INFORMATION SEARCH

\begin{tabular}{|c|c|c|c|c|c|c|}
\hline & $\mathrm{N}$ & Mean & \multicolumn{2}{|c|}{ Std. Deviation } & \multicolumn{2}{|c|}{ Std. Error } \\
\hline $18-29$ years old & 170 & 3.89 & \multicolumn{2}{|c|}{.945} & \multicolumn{2}{|c|}{.072} \\
\hline $30-39$ years old & 153 & 3.90 & \multicolumn{2}{|l|}{.951} & \multicolumn{2}{|c|}{.077} \\
\hline $40-49$ years old & 70 & 4.01 & \multicolumn{2}{|l|}{.771} & \multicolumn{2}{|c|}{.092} \\
\hline $50-59$ years old & 29 & 3.66 & \multicolumn{2}{|l|}{1.045} & \multicolumn{2}{|c|}{.194} \\
\hline 60 years or older & 3 & 3.33 & \multicolumn{2}{|l|}{1.528} & \multicolumn{2}{|c|}{.882} \\
\hline \multirow[t]{3}{*}{ Total } & 425 & 3.89 & \multicolumn{2}{|l|}{.932} & \multicolumn{2}{|c|}{.045} \\
\hline & & Mean & & & $\begin{array}{l}95 \% \mathrm{Cc} \\
\text { Interva }\end{array}$ & idence \\
\hline & (J) Age & $\begin{array}{l}\text { Difference } \\
(\mathrm{I}-\mathrm{J})\end{array}$ & Std. Error & Sig. & $\begin{array}{l}\text { Lower } \\
\text { Bound }\end{array}$ & $\begin{array}{l}\text { Upper } \\
\text { Bound }\end{array}$ \\
\hline \multirow[t]{4}{*}{$18-29$ years old } & $30-39$ years old & -.014 & .104 & 1.000 & -.30 & .27 \\
\hline & $40-49$ years old & -.126 & .132 & .876 & -.49 & .24 \\
\hline & $50-59$ years old & .233 & .187 & .725 & -.28 & .75 \\
\hline & 60 years or older & .555 & .543 & .035 & -.93 & 2.04 \\
\hline \multirow[t]{4}{*}{$30-39$ years old } & $18-29$ years old & .014 & .104 & 1.000 & -.27 & .30 \\
\hline & $40-49$ years old & -.112 & .134 & .919 & -.48 & .26 \\
\hline & $50-59$ years old & .247 & .189 & .687 & -.27 & .76 \\
\hline & 60 years or older & .569 & .543 & .033 & -.92 & 2.06 \\
\hline \multirow[t]{4}{*}{$40-49$ years old } & $18-29$ years old & .126 & .132 & .876 & -.24 & .49 \\
\hline & $30-39$ years old & .112 & .134 & .919 & -.26 & .48 \\
\hline & $50-59$ years old & .359 & .206 & .407 & -.20 & .92 \\
\hline & 60 years or older & .681 & .549 & .028 & -.82 & 2.19 \\
\hline \multirow[t]{4}{*}{$50-59$ years old } & $18-29$ years old & -.233 & .187 & .725 & -.75 & .28 \\
\hline & $30-39$ years old & -.247 & .189 & .687 & -.76 & .27 \\
\hline & $40-49$ years old & -.359 & .206 & .407 & -.92 & .20 \\
\hline & 60 years or older & .322 & .565 & .979 & -1.23 & 1.87 \\
\hline \multirow[t]{4}{*}{60 years or older } & $18-29$ years old & -.555 & .543 & .035 & -2.04 & .93 \\
\hline & $30-39$ years old & -.569 & .543 & .033 & -2.06 & .92 \\
\hline & $40-49$ years old & -.681 & .549 & .028 & -2.19 & .82 \\
\hline & $50-59$ years old & -.322 & .565 & .979 & -1.87 & 1.23 \\
\hline
\end{tabular}

Dependent Variable: Information search

Tukey HSD

The results further showed that regarding age and purchase decision, this was observed highest among respondents 60 years of age and older. The post-hoc test revealed that the only statistically significant difference in the importance of purchase decision was between those aged 50 - 59 years old and those aged 60 years and older $(M D=0.908 ; p=0.015)$. The results also showed that regarding the socioeconomic level and need recognition, that those participants who had incomes earning $\$ 86,000$ or more had a higher mean rating for need recognition. The post-hoc test revealed that there was a statistically significant difference between those who earned $\$ 25,000$ or less and those who earned $\$ 86,000$ or more regarding need recognition $(\mathrm{MD}=-.3531 ; p=0.037)$. There were no significant differences between the other pairs $(p>$ $.05)$.

The results further showed regarding the socioeconomic level and promotion, that those who earned $\$ 86,000$ or more rated promotion the least. The post-hoc test indicated that there was a significant difference with those that earned $\$ 86,000$ or more and those who earned between $\$ 26,000$ and $\$ 45,000(M D=0.716$; $p=0.000)$. The rest of the pairs were not statistically significant. Moreover, the results showed that 
regarding the socioeconomic level and process, that those with incomes of $\$ 86,000$ or more had a higher mean rating for the process involved with obtaining the service. The post-hoc test revealed that there were statically significant differences with those who earned $\$ 26,000$ - $\$ 45,000 ; \$ 46,000$ - $\$ 65,000 ; \$ 66,000$ $\$ 85,000$; and $\$ 86,000$ or more than those who earned $\$ 25,000$ or less $(M D=0.294 ; p=0.007 ; M D=0.257$; $p=0.023 ; M D=0.224 ; p=0.018 ; \mathrm{MD}=0.294 ; p=0.011$, respectively). The results do show that higher earners were more concerned with the process involved with obtaining the service over the lowest earners.

Regarding education and place, those with a high school diploma were more concerned with the place where the service was being performed than those with higher levels of education. The post-hoc analysis indicated that statistical significance was found with participants having a high school diploma and those with a bachelor's and master's degree $(M D=0.662 ; p=0.003$; $\mathrm{MD}=0.705 ; p=0.004$, respectively). Likewise, statistical significance was found with participants having an associate's degree and those with a bachelor's degree $(M D=0.454 ; p=0.046)$. The other pairs were not statistically significant. The results showed that the participants with lower levels of education were more concerned with the place the service was being performed than participants with higher levels of education.

Regarding education level and process, the higher educated the participant was the more important the process involved in obtaining the service was. The post-hoc test showed there was a significant difference between those with a high school diploma and those with a doctorate degree $(M D=0.688 ; p=0.016)$. The second significant difference was found between those with an associate's degree and those with a master's degree $(M D=0.442 ; p=0.012)$. The third difference was found between those with an associate's degree and those with a doctorate degree $(M D=0.921 ; \mathrm{p}=0.007)$. There was also a significant difference found between respondents with a bachelor's degree and those with a master's degree $(M D=0.359 ; p=0.008)$. The last significant difference was observed between those with a bachelor's degree and those with a doctorate degree $(M D=0.837 ; p=0.036)$. The results do confirm that the importance of the process involved in obtaining the service was higher among respondents who had a higher level of education than those with lower levels of education.

Lastly, regarding education level and physical evidence, the lower the education level of the participant the more concerned the participant was regarding the physical evidence of the service. The post-hoc analysis confirmed that there was a significant difference between those with a high school diploma and those with a doctorate degree $(M D=0.500 ; p=0.013)$. The second significant difference was found between those with an associate's degree and those with a doctorate degree $(M D=0.500 ; p=0.016)$. The rest of the differences were not statistically significant $(p>.05)$.

\section{CONCLUSIONS}

Based on the results of this study, there is evidence that shows that there are statistically significant associations regarding the 8 Ps marketing mix of service product; price; place; promotion; people; process; physical evidence; and productivity and the buyer decision-making process of need recognition; information search; evaluation of alternatives; purchase decision; and post-purchase behavior. There were likewise statistically significant associations found with the two aforementioned constructs and the sociodemographic variables of age; gender; ethnicity; socioeconomic level; and education level.

When reviewing the hypotheses, hypothesis 1 was supported with Model 2 when the sociodemographic variables were controlled. The predictive capacity was increased on all five buyer decisionmaking process variables. When reviewing hypothesis 2 , socioeconomic level and education level were the two socioeconomic variables that had the most influence on the 8 Ps marketing mix in the areas of place; promotion; process; and physical evidence. Lastly, when reviewing hypothesis 3 , age and socioeconomic level had the most influence on the buyer decision-making process.

To recap, younger participants aged 18 - 49 years old did more information searching on serviceoriented products. Younger people are typically more well-informed of the latest technologies and apps where information searching for service products is more readily available. However, knowing this information, marketing professionals can be more aware of how older people are able to information search for service products and then tailor marketing efforts to the searching tools that older people most readily 
use. For example, if the target market for a service product is older people, then having the marketing campaign run on television; radio; outdoor advertising; or print media would be better advertising mediums for this target group. Conversely, if the target market is younger consumers, having an advertising or promotional presence on the Internet or through cell phone apps, for example, would be most advantageous.

The purchase decision was rated highest among participants 60 years of age and older. This indicates that older consumers do not waste a lot of time searching for information or evaluating different service options before making a purchase decision. Marketing professionals armed with this information need to be savvier when it comes to marketing service products to older people. Differentiating service product features would be beneficial to sway older people who are less concerned about spending a lot of time on deciding what service provider to choose. Moreover, based on this study, participants who had higher incomes of $\$ 86,000$ or more rated need recognition with more importance. To speculate, people who have higher incomes are more aware of their personal individual service product needs quicker. Company leaders; marketing leaders; and sales representatives need to swiftly point out any service product that could be beneficial to people in this income bracket because the chance of closing the sale is higher.

Regarding the importance of having a discount on a service product, this was rated the least with higher income earners. Marketers need to be more concerned with applying promotional and sales discounts on service-oriented products to lower-earning target markets. For higher-earning target markets, companies can save money by not discounting the service product because higher earners are not as concerned with saving money on service-oriented products based on the findings of this study. However, the process involved with obtaining the service is more important with higher earners. Consumers in this wage classification need to be cared for and tended to more in order to provide fulfilling service product experiences and to help secure repeat business.

Regarding the importance of the place where the service would be performed, participants with lower levels of education were more concerned with where the service place was located. Ruling out the importance of service place with lower educated consumers would not be beneficial for company leaders or marketers. For example, companies believing that only higher educated customers are more concerned with products that are delivered from "store-to-door" and assuming that lower educated customers prefer brick-and-mortar stores or buying on the Internet could prove to be a marketing mistake based on this study. Eliminating these buyer stereotypes would be beneficial for company leaders and marketing personnel.

Moreover, the process involved with obtaining the service was most important amongst higher educated participants. This was not a surprising find since higher educated consumers are more likely to spend larger sums of money on service products (i.e., hair salons, car shopping). However, company leaders and marketers equipped with this finding in this study can see the importance of making sure that the higher educated customers are treated well in order to retain these consumers better. If these types of customers are not happy with the final service product, then looking elsewhere the next time the service will need to be filled will not be an issue. Lastly, those participants with lower levels of education were more concerned with the overall physical evidence of the service product. To speculate, consumers with lower levels of education could be mirroring the service product experience with additional familiarities such as seen on social media outlets or experiences made through friends (Houser, 2016).

This research did not come without any limitations. This study was a convenience sample and undertaking a future research study using a random sample would be beneficial. Additionally, there was a potential source of age bias, as the sample was comprised mainly of $18-39$ years old $(76 \%)$. However, this study does further the literature by adding to both bodies of work pertaining to the 8 Ps marketing mix and the buyer decision-making process. The results of this study can open future research endeavors from several angles due to the number of variables that were analyzed in this study. Many spin-off research studies can be generated using some or a few of the variables in this study to gain more focused and newfound perspectives. Lastly, value to the practice was found through this research study. For example, company leaders and marketing personnel on all levels from customer service to upper executives can benefit from the results of this study by tailoring sales pitches and marketing campaigns to better align and run in tandem with the service product, the target market, and the marketing campaign in a more knowledgeable, focused and buyer decision-making manner. 


\section{ACKNOWLEDGEMENT}

We would like to thank Dr. Gary Ngara for his valuable comments and support in earlier drafts of this manuscript. His feedback was extremely helpful in preparing this article in its current form.

\section{REFERENCES}

Ahmad, W.M.A.B.W. (2018). Sample Size Calculation Made Easy Using G*Power. Penerbit USM, Malaysia. ISBN: 978-967-461-255-9

Basker, E. (2015). Change at the checkout: Tracing the impact of a process innovation. The Journal of Industrial Economics, 63(2), 330-370.

Belhekar, V.M. (2016). Statistics for Psychology Using R. Thousand Oaks, CA: Sage.

Berry, J. (2013). The secret life of bar codes. Wirksworth Books.

Bhattacharya, H. (2013). Service business: Some reflections. International Journal of Economics \& Business Studies, 3(1), 11-19.

Booms, B.H., \& Bitner, M.J. (1981). Marketing strategies and organization structures for service firms. Marketing Services, pp. 47-51.

Booms, B.H., \& Bitner, M.J. (1980). New management tools for the successful tourism manager. Annals of Tourism Research, 7(3), 337-352.

Branchik, B.J., \& Shaw, E.H. (2015). Net transaction value: A model of high-involvement decisionmaking in buyer choice behavior. Atlantic Marketing Journal, 4(2), 1-19.

Bushong, G.J., \& Koku, P.S. (2012). Look before you leap: Marketing advice for small firms. CPA Journal, 82(5), 52-59.

Coculescu, B.I., Purcarea, V.L., \& Coculescu, E.C. (2016). Product policy - The main component of the marketing mix in the Romanian health services. Journal of Medicine \& Life, 9(1), 49-51.

Dewey, J. (1910). How we think. Heath.

Dugard, P., Todman, J., \& Staines, H. (2010). Approaching multivariate analysis: A practical introduction (2nd ed.). Routledge/Taylor \& Francis Group.

Dimitrov, D.M. (2014). Statistical Methods for Validation of Assessment Scale Data in Counseling and Related Fields. Wiley: New York.

Engel, J.F., Blackwell, R.D., \& Miniard, P.W. (1986). Consumer behavior (5th ed.). Dryden.

Engel, J.F., Kollat, D.T., \& Blackwell, R.D. (1978). Consumer behavior (3rd ed.). Dryden.

Field, A.P. (2016). Discovering statistics using SPSS. London, England: SAGE.

Haddara, M., Hsieh, J., Fagerstrøm, A., Eriksson, N., \& Sigurðsson, V. (2020). Exploring customer online reviews for new product development: The case of identifying reinforcers in the cosmetic industry. Managerial \& Decision Economics, 41(2), 250-273.

Heidari, H. (2017). Investigating the effects of pricing and productivity on sales. International Journal of Economic Perspectives, 11(1), 930-936.

Houser, M. (2016). Why Teens Today Wear the Brands They Wear and How This is Affected by Reference Groups. Marketing Undergraduate Honors Theses, 32.

Holmes, A., Illowsky, B., \& Dean, S. (2017). Introductory Business Statistics. OpenStax. Rice University. Jaggia, S., \& Kelly, A. (2013). Business Statistics, Communicating with Numbers. McGraw-Hill, Irwin.

Joseph-Williams, N., Edwards, A., \& Elwyn, G. (2011). The importance and complexity of regret in the measurement of 'good' decisions: A systematic review and a content analysis of existing assessment instruments. Health Expectations, 14(1), 59-83.

Kesavan, D., \& Vanniarajan, T. (2016). Financial inclusion int: Servqual approach. Global Management Review, 10(2), 15-31.

Koban-Roess, E. (2013). Gender Differences in Complaint Behaviour and Implications for the Complaint Management Process. 
Kruger, H., Fourie, L., \& Terblanche, N. (2005). Offline/online brand element transmutation and tangible/intangible product characteristics within various South African retail brand categories: An exploratory study. South African Journal of Business Management, 36(3), 15-28.

Lala, G.A. (2016). The importance of knowledge in the consumer's decision-making process. Analele Universitatii 'Eftimie Murgu' Resita. Fascicola II. Studii Economice, pp. 147-158.

Lovelock, C., \& Wright, L. (2002). Principles of services marketing and management (2nd ed.). Prentice Hall.

Mathur, D. (2018). Policing: Reinvention strategies in a marketing framework. South Asian Journal of Management, 25(2), 214-216.

Moore, R.S., Collier, J.E., Williams, Z., \& Moore, M.L. (2020). Perceived market orientation in the product return experience and its impact on post-purchase behavior. Journal of Marketing Theory \& Practice, 28(3), 213-225.

Mukherjee, S., \& Shivani, S. (2016). Marketing mix influence on service brand equity and Its dimensions. Vision, 20(1), 9-23.

Newsom, J.T. (2018). Minimum Sample Size Recommendations. Psy 523/623 Structural Equation Modeling, Spring 2018.

Nyarku, K., \& Agyapong, G. (2011). Rediscovering SWOT analysis: The extended version. Academic Leadership, 9(2), 257-273.

Shrivastava, A., \& Bisen, V. (2014). Impact of advertisement on consumers' buying behavior: A study on FMCG products in Lucknow city. CLEAR International Journal of Research in Commerce \& Management, 5(4), 1-5.

Stafford, M.B., Reilly, T., Grove, S.J., \& Carlson, L. (2011). The evolution of services advertising in a services-drive national economy. Journal of Advertising Research, 51(1), 136-148.

Stoica, L.C., Cristescu, M.P., \& Stancu, A-M.R. (2018). Relationship of consumer management and marketing strategy. Knowledge Horizons - Economics, 10(1), 70-78.

Svatošová, V. (2013). Motivation of online buyer behavior. Journal of Competitiveness, 5(3), 14-30.

Tevšić, D., \& Nanić, A. (2020). Research of gender-based behavioural differences in the purchasing decision-making process. Economic Review: Journal of Economics \& Business, 18(1), 75-86.

Thaichon, P., Jebarajakirthy, C., Tatuu, P., \& Gajbhiyeb, R.G. (2018). Are you a chocolate lover? An investigation of the repurchase behavior of chocolate consumers. Journal of Food Products Marketing, 24(2), 163-176.

Vaccaro, V.L., \& Cohn, D.Y. (2004). The evolution of business models and marketing strategies in the music industry. The International Journal on Media Management, 6(1/2), 46-58.

Wirtz, J. (2020). Viewpoint: Service products, development of service knowledge and our community's target audience. Journal of Services Marketing.

Yang, C-C., Cheng, L-Y., \& Lin, C.J. (2015). A typology of customer variability and employee variability in service industries. Total Quality Management \& Business Excellence, 26(7/8), 825839. 